\title{
Peat swamps at Giral lignite field of Barmer basin, Rajasthan, Western India: understanding the evolution through petrological modelling
}

\author{
Prakash K. Singh ${ }^{1}$ P. K. Rajak ${ }^{1}$ M. P. Singh ${ }^{1}$ - V. K. Singh ${ }^{1}$ A. S. Naik ${ }^{1}$ Alok K. Singh ${ }^{2}$
}

Received: 25 November 2015/Revised: 23 January 2016/Accepted: 23 February 2016/Published online: 21 July 2016

(C) The Author(s) 2016. This article is published with open access at Springerlink.com

\begin{abstract}
The lignite samples collected from Giral lignite field of Barmer basin have been subjected to petrological investigation. The data generated has been discussed to understand the evolution of the paleomires of these lignites. The present study reveals that these low rank $\mathrm{C}$ coals are chiefly composed of huminite group macerals, mainly telohuminite and detrohuminite, while liptinite and inertinite group macerals occur in subordinate amounts. Not much variation in the maceral composition from Seam-I to Seam-VIII has been observed. Barmer lignites are characterized by a very high GI $(>10)$ and moderate TPI indicating topogenous mire in the basin which was permanently flooded. The GI and TPI values and the petrography-based facies critical models indicate that these lignites originated mostly under wet forest swamp to clastic marsh having telmatic to limno-telmatic conditions with a moderate rate of subsidence and a very slow fall in ground water table. Further, the GWI and VI values are suggestive of mesotrophic to rheotrophic hydrological conditions having the dominance of herbaceous to marginal aquatic vegetation. There were spells of periodic drowning of peat especially during the formation of Seam-VII. Moderately high concentration of calcium in these lignites along with the presence of framboidal pyrite indicate enhanced sulphate-reducing bacterial activity present in carbonate and sulphate-rich waters in the basin during peat formation.
\end{abstract}

Keywords Peat swamp $\cdot$ Petrography $\cdot$ Giral lignite $\cdot$ Barmer basin $\cdot$ Western India

\section{Introduction}

The relation of petrographic elements with the evolution of peat swamps has been studied by a number of researchers (Teichmüller 1950, 1962, 1989; Thompson 1951; Teichmüller and Thompson 1958; Hiltmann 1976; Schneider 1978, 1980; von der Brelie and Wolf 1981; Diessel 1982, 1986; Hunt et al. 1986; Kalkreuth et al. 1991; Singh and Singh 1996; Singh et al. 2010a, b, 2012a, b, 2013).

Prakash K. Singh

prakashbhu@rediffmail.com

1 Coal \& Organic Petrology Lab, Centre of Advanced Study in Geology, Banaras Hindu University,

Varanasi 221005, Uttar Pradesh, India

2 Rajiv Gandhi Institute of Petroleum Technology, Rae Bareli 229316, UP, India
There is general agreement on the factors such as the type of peat-forming flora, climate, geomorphologic, and tectonic framework, but the precise role of these factors is still a subject of interest and further study. In India, most of the petrographic studies relating to the evolution of peat swamps are on Gondwana coals and not much has been done on lignites. Although, some lignite deposits have been investigated by Singh et al. (2010a, b, 2012a, b, c), but such studies are lacking with the Rajasthan lignites, especially those of the Barmer basin, the current study area (Fig. 1).

Development of Barmer basin is considered as a composite, second-order graben which is indicated by the presence of Cretaceous-Paleocene volcanogenic sediments (Sharma 2007). Initially, terrestrial sediments of the Jurassic to Cretaceous periods were deposited while there was deposition of coastal, marine, and shallow water sediments during Paleocene to Eocene period (Sharma 2007). It is believed that the fragmentation of Gondwanaland during 


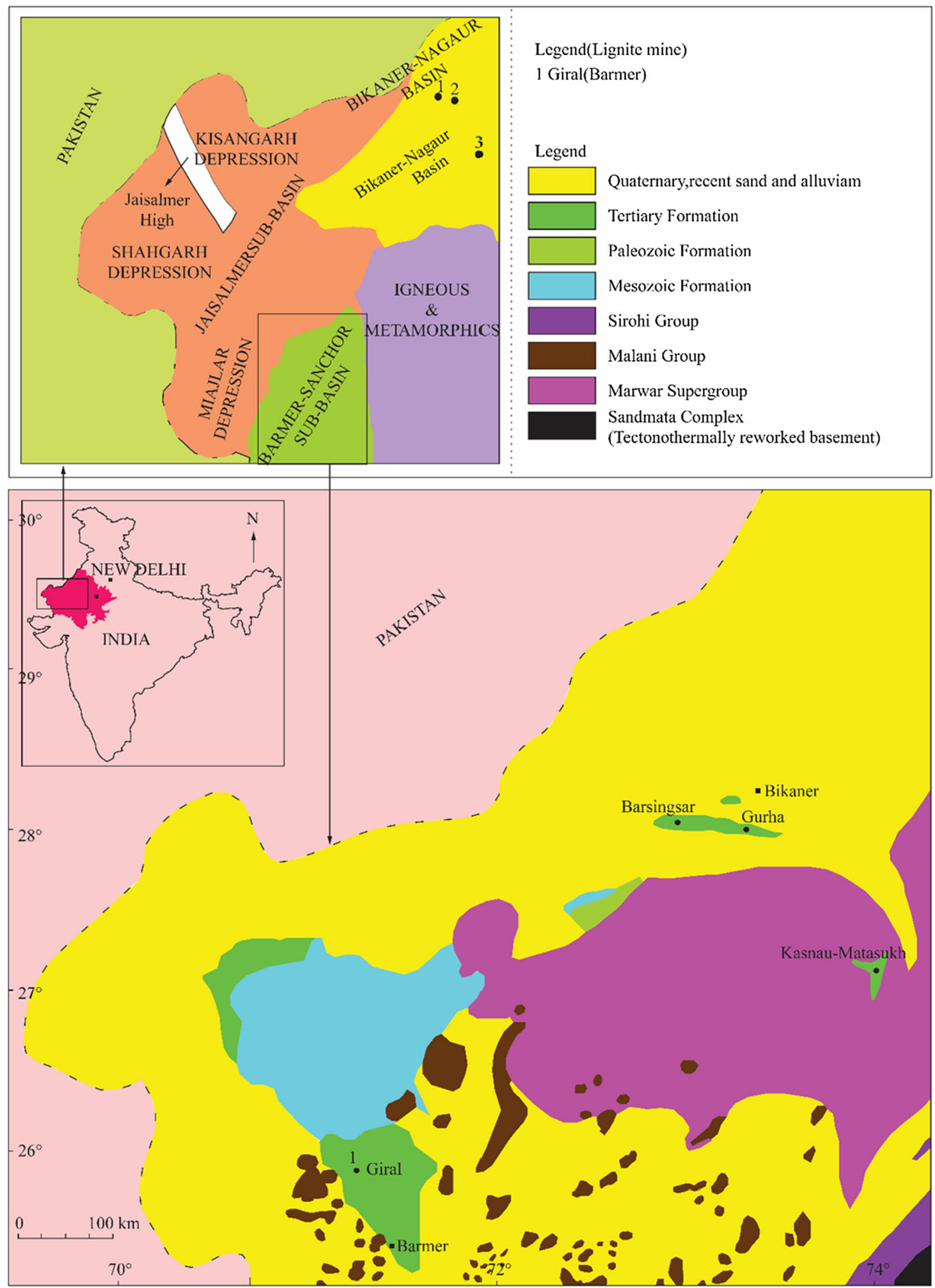

Fig. 1 Regional geological map of northern part of Rajasthan showing Barmer Basin (after Roy and Jakhar 2002)

Mesozoic caused extensional tectonics in the northwestern Indian shield. The extensional tectonics continued and resulted into deep fractures in the continental and oceanic lithosphere. This led to the development of rift basins in Gujarat and Rajasthan (Sharma 2007). The Cambay-Sanchor-Barmer rift formed within the continental lithosphere. 
Lignite was initially reported in this basin, by Oldham (1886) who carried out systematic mapping. Subsequently, various aspects of the area were studied by a number of workers on (La Touche 1902; Bhola 1946; Barooah 1946; Siddiquie 1963; Deshmukh and Mishra 1971). Siddiquie and Bahl (1965) initially worked out on the lignite-bearing Akli Formation (Fig. 2). This Formation has two members, the lowermost is the Thumbli Member and the upper one is Akli Bentonite Member (Das Gupta 1974; Sisodia and Singh 2000). The lower member consists of sandstones, lignites, and shales which were deposited in a lagoonal, delta-front setting while the upper one comprises of shallow marine bentonite clays. Ash-grey to dark-brown lignitic clay, lignite, clay, and siltstones are associated with the lignite seams. These lignite seams laterally as well as vertically grade into carbonaceous clay and lignitic clay. The occurrence of lignite has been reported from BotiyaBharka and Giral area in Barmer basin (Joshi et al. 1990). The exploratory drilling carried out by Geological Survey of India (GSI) in the Botiya-Bharka-Thumbli area indicates that the lignite seams are not persistent in quality as well as quantity (Bhattacharya and Dutta 1985). They occur at depths of 6-100, 100-160, and 160-241 m from the surface and are respectively named zones A, B, and C. The lignite seams maintain low dip of $3^{\circ}-4^{\circ}$ and are spread over a $3-\mathrm{km}$ strike length and $1.5 \mathrm{~km}$ down dip (Jodha 2003). The lignite seams are thin and the individual seams vary in thickness from 0.3 to $7.20 \mathrm{~m}$ (Jodha 2003).

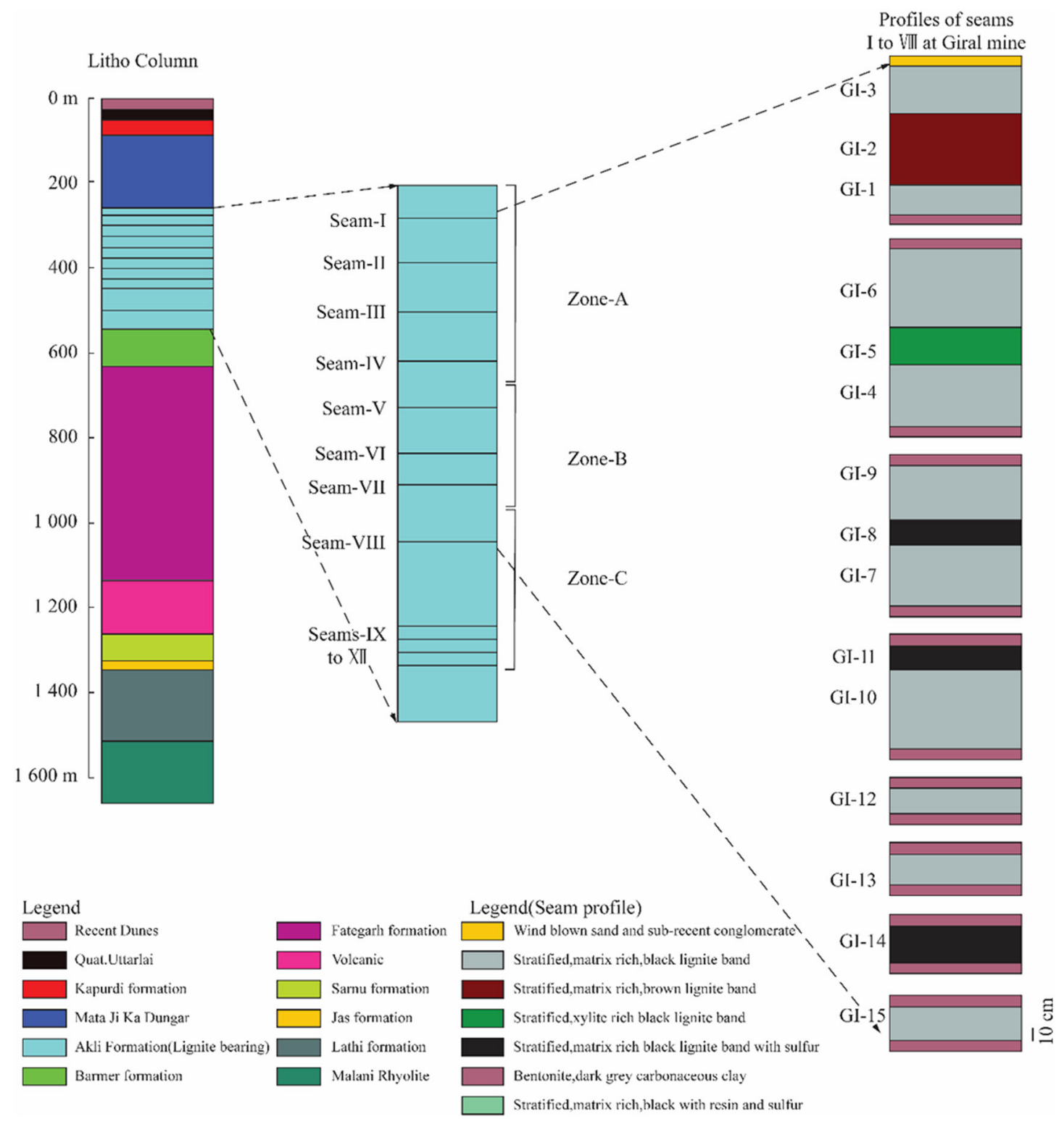

Fig. 2 Litho column showing various rock units in Barmer Basin along with lignite seam profiles at Giral 
Thickness of seams is function of subsidence and peat accumulation rate (McCabe 1991). Considering the thin lignite seams in the basin, it appears that peat accumulation could not keep pace with basin subsidence for long time and the subsidence exceeded peat accumulation rate. The sedimentary sequences of Middle Jurassic to Early Eocene were deposited under shallow marine to fluviatile environment (Jodha 2003). In the eastern and central part of the Barmer basin there is merging of fluvial sediments of Akli formation with the near shore to shallow inner shelf marine sediments. The core samples analysed by GSI have yielded numerous palynomorphs. Their studies have shown the presence of Proxaperitites, Spinizonocolpites, and spinose grains in high concentration which are comparable with the Paleocene-early Eocene sediments of India (Jodha 2003). Based on the palynotaxa recovered from the Akli succession of Barmer like Dandotiaspora dilate, Lygodiumsporites lakiensis, Proxapertites cursus, Kielmeyerapollenites eocenicus, and Palmidites plicatus, Tripathi et al. (2009) assigned a late Paleocene (Thanetian to Ypresian) age to the Akli Formation. They observed relatively high abundance of biodegraded phytoclasts compared to other lithotypes in the lignite seams.

The present work aims to study the vertical variation of petrographic and chemical attributes and based on them evolution of the paleomire of these lignites has been discussed.

\section{Geological setting}

The Barmer basin is a narrow, elongated rift graben which trends in north-south direction over a length of $100 \mathrm{~km}$. The eastern and western margin of basin is bounded by faults. Oriented along north-south a number of sub-basins also occur which run parallel to the basin edge. The main basin is floored by Malani Igneous Complex and pre-rift sedimentation of Paleozoic and Jurassic. Established delta systems formed during post rift period and are represented by the Mataji-Ka-Donger and Akli Formations. The Akli Formation comprises of delta plain and lagoonal shales, sandstones and lignites with clay rich bentonite.

It is believed that epi-orogenic movements that occurred during early Jurassic period resulted in subsidence and formation of Kachchh and Sanchor basins in south and Jaisalmer basin in the central portion. Subsequently, the movements during the Late Cretaceous period caused subsidence as well as fracturing and converted the Barmer basin into a graben (Compton 2009). The gravity and magnetic surveys in Jaisalmer and Barmer were taken during 1955-1956 (Bose 1956). The area has subsequently been explored in detail for its hydrocarbon potential through geological and geophysical tools by Oil and Natural Gas Corporation (ONGC). The Barmer basin is connected to the Cambay basin through tectonic embayment. There are numerous cross-trends within the basin graben which occur in the form of transverse and oblique faults, uplifts, and geomorphic lineaments. The formations have a regional trend of NNE-SSW with $3^{\circ}-$ $4^{\circ}$ dip towards SE. Subsurface data indicates the presence of several intra-basinal normal oblique and cross faults consequently forming horst and graben structure (Jodha 2003) and disrupting the lignite occurrences. Based on the dominance of calcium carbonate, attapulgite, and xerophytic flora recovered from the fullers' earth, it is suggested that arid environment commences during early Eocene (Jodha 2003).

The general stratigraphic succession of the Barmer basin based on the informations compiled through several sources, are furnished in Table 1 while the general geological map of the area is shown in Fig. 1. The lithocolumn along with the megascopic seam profile is presented in Fig. 2.

\section{Method of study}

Lignite samples were collected from Seam-I to SeamVIII from Giral mine of Barmer basin, Rajasthan (Fig. 1) adopting pillar sampling method as per Schopf (1960). The lignite samples were crushed and reduced in quantity through quartering and coning to prepare $31 \mathrm{com}$ posite samples (from 102 number of individual lignite samples) and were analysed for their petrographic and chemical composition. The -18 mesh size samples were used to prepare polished mounts for petrography and -70 mesh size samples were used for proximate analysis. Maceral analysis was performed on a Leitz Orthoplan-Pol Microscope equipped with Wild Photoautomat MPS-45 in the Coal and Organic Petrology Laboratory, Centre of Advanced Study in Geology, Banaras Hindu University. The line-to-line and point-to-point spacing was $0.4 \mathrm{~mm}$ and more than 600 counts were taken on each sample. The method described by Taylor et al. (1998) was followed; huminite macerals were termed and described following ICCP-1994 system (Sykorova et al. 2005) whereas the recommendations of ICCP (2001) was followed for the inertinite macerals. The proximate analysis was carried out following BIS (2003). The elemental analysis $(\mathrm{C}, \mathrm{H}, \mathrm{N}, \mathrm{O}$, and $\mathrm{S})$ was performed at CMPDI, Ranchi. The vitrinite/huminite reflectance was measured at National Metallurgical Laboratory, Jamshedpur and a minimum of 200 measurements were taken on each sample. The Rock-Eval-6 pyrolysis has been carried out at Research and Development, Oil India Ltd, Duliajan, Assam. 
Table 1 General stratigraphic succession in the Barmer Basin, Rajasthan (compiled after Deshmukh and Mishra 1971; Das Gupta 1974; Bhandari 1999)

\begin{tabular}{|c|c|c|c|c|}
\hline Age & Formation & Lithology & Fossils & $\begin{array}{l}\text { Thickness } \\
(\mathrm{m})\end{array}$ \\
\hline Recent & Dune sand and sediments & $\begin{array}{l}\text { Alluvium, sands, river alluvium and } \\
\text { gravel wash }\end{array}$ & & \\
\hline Sub-recent and (?) older & Uttarlai Formation & $\begin{array}{l}\text { Thin gypsum- limestone and salt } \\
\text { sequence, with unconsolidated sands, } \\
\text { kankar and gravel beds }\end{array}$ & & $3-4$ \\
\hline \multicolumn{5}{|l|}{ Unconformity } \\
\hline \multirow[t]{4}{*}{ Eocene } & Kapurdi formation & $\begin{array}{l}\text { Lacustrine Fuller's earth deposits (?) } \\
\text { interbeded with marine bioclastic } \\
\text { limestone }\end{array}$ & $\begin{array}{l}\text { Molluscs, echinoids, } \\
\text { fishes, carbonaceous } \\
\text { plant remains etc. }\end{array}$ & 30 \\
\hline & Mataji Ka Dungar formation & $\begin{array}{l}\text { Shallow marine orthoquartzite and hard } \\
\text { sandstone with pisolites and ball clay } \\
\text { and impure bentonitic clay bands at the } \\
\text { base }\end{array}$ & - & 180 \\
\hline & Unconformity & & & \\
\hline & $\begin{array}{l}\text { Akli Formation } \\
\text { Akli Bentonite member } \\
\text { Thumbli member }\end{array}$ & $\begin{array}{l}\text { Volcanogenic bentonite sequence at the } \\
\text { top and sandstone, lignite sequence in } \\
\text { the basal part }\end{array}$ & $\begin{array}{l}\text { Leaves pollen, spores, } \\
\text { forams, ostracods and } \\
\text { molluscs }\end{array}$ & 280 \\
\hline \multirow[t]{3}{*}{ Paleocene } & $\begin{array}{l}\text { Barmer Formation } \\
\text { Mandai member } \\
\text { Barmer hill member }\end{array}$ & $\begin{array}{l}\text { Shallow marine sandstone with rare plant } \\
\text { fossils and orthoquartzite bands grading } \\
\text { into conglomerate, sandstone with plant } \\
\text { fossils and volcanogenic clay }\end{array}$ & & 80 \\
\hline & $\begin{array}{l}\text { Fategarh Formation fategarh } \\
\text { scarp member } \\
\text { Vinjori Member }\end{array}$ & $\begin{array}{l}\text { Sandsone layer with mixed bivalve and } \\
\text { gastropod casts at the top, Dominatly of } \\
\text { ochrous clay bands, variegated sandy } \\
\text { siltstone and sandstone sequence with } \\
\text { coquina beds }\end{array}$ & $\begin{array}{l}\text { Molluscs, echinoid bone } \\
\text { fragments, for ams and } \\
\text { plant remain }\end{array}$ & 520 \\
\hline & Volcanic Formation (?) & $\begin{array}{l}\text { Acid to basic volcanic rocks mainly in } \\
\text { form of sills and dykes and local } \\
\text { intrusive porphyrites }\end{array}$ & & \\
\hline \multicolumn{5}{|l|}{ Intrusive contact } \\
\hline Cretaceous & Sarnu Formation & $\begin{array}{l}\text { Indurated, terrestrial sandstone and } \\
\text { siltstone with plant fossils }\end{array}$ & & 80 \\
\hline \multicolumn{5}{|l|}{ Unconformity } \\
\hline Callovo-Oxfordian & Jaisalmer Formation & $\begin{array}{l}\text { Marine, fossiliferous, arenaceous } \\
\text { limestone }\end{array}$ & & 15 \\
\hline Bathonian to Lias & Lathi Formation (?) & $\begin{array}{l}\text { Terrestrial arenaceous sequence with } \\
\text { wood fossils and fossiliferous tree trunk }\end{array}$ & Wood and leaves & \\
\hline Precambrian & Malani Suite of Igneous rocks & Rhyolite and granite & & \\
\hline
\end{tabular}

\section{Result and discussion}

\subsection{Petrographic composition}

Megascopically, the lignite seams consist dominantly of stratified black bands. Most of the bands contain patches of resin which is visible and few of them also show specks of pyrite. The lignites of Barmer basin are composed chiefly of huminite-group macerals while liptinite and inertinite group of macerals occur in subordinate amounts (Table $2 \mathrm{a}, \mathrm{b}$ ).
There is not much variation in the maceral composition from Seam-I to Seam-VIII. Huminite (85.9 vol\%, mean of all the seams on mmf basis) comprises mainly telohuminite and detrohuminite. Telohuminite is mainly composed of ulminite-A $(24.4 \%)$ and ulminite-B (20.9\%). Detrohuminite comprises densinite $(32.2 \%)$ and attrinite $(7.6 \%)$. Gelohuminite is present in very small amount. Textinite rarely occurs in these lignite seams and mostly shows lamellar structure. Ulminite is normally homogeneous in nature and at places fractures have been observed which are filled up 
Table 2a Maceral composition (vol\%) of Barmer Basin lignite, Rajasthan

\begin{tabular}{|c|c|c|c|c|c|c|c|c|c|}
\hline Seam no. & VIII & VII & VI & $\mathrm{V}$ & IV & III & II & $\mathrm{I}$ & Mean of all seams \\
\hline \multicolumn{10}{|l|}{ Maceral } \\
\hline Textinite-A & 0.0 & 0.2 & 0.0 & 0.0 & 0.1 & 0.0 & 0.0 & 0.1 & 0.0 \\
\hline Textinite-B & 0.0 & 0.4 & 0.2 & 0.0 & 0.0 & 0.2 & 0.1 & 0.1 & 0.1 \\
\hline Ulminite-A & 23.9 & 10.9 & 28.0 & 19.8 & 22.9 & 18.6 & 23.2 & 25.6 & 21.6 \\
\hline Ulminite-B & 18.0 & 10.5 & 13.9 & 17.3 & 24.7 & 21.5 & 19.4 & 22.6 & 18.5 \\
\hline Attrinite & 11.1 & 9.3 & 2.4 & 10.7 & 6.6 & 3.8 & 5.6 & 4.0 & 6.7 \\
\hline Densinite & 18.5 & 47.3 & 31.7 & 27.6 & 20.8 & 33.3 & 26.7 & 21.6 & 28.4 \\
\hline Phlobaphinite & 1.0 & 0.4 & 0.0 & 0.6 & 0.9 & 0.3 & 0.5 & 0.9 & 0.6 \\
\hline Total & 72.4 & 79.1 & 76.1 & 75.9 & 76.0 & 77.7 & 75.4 & 74.8 & 75.9 \\
\hline Sporinite & 1.4 & 0.6 & 2.0 & 0.2 & 0.7 & 0.7 & 1.5 & 0.9 & 1.0 \\
\hline Cutinite & 0.8 & 0.8 & 0.2 & 0.2 & 0.3 & 0.2 & 0.7 & 0.6 & 0.5 \\
\hline Resinite & 4.9 & 6.2 & 3.7 & 4.1 & 4.4 & 4.4 & 4.2 & 3.9 & 4.5 \\
\hline Suberinite & 0.0 & 0.0 & 0.4 & 0.0 & 0.0 & 0.0 & 0.0 & 0.0 & 0.0 \\
\hline Liptodetrinite & 1.2 & 1.2 & 1.0 & 1.2 & 1.4 & 1.8 & 1.6 & 1.5 & 1.3 \\
\hline Bituminite & 0.0 & 0.0 & 0.0 & 0.0 & 0.0 & 0.0 & 0.0 & 0.0 & 0.0 \\
\hline Fluorinite & 0.4 & 0.0 & 0.4 & 0.6 & 0.4 & 0.0 & 0.4 & 0.4 & 0.3 \\
\hline Alginite & 0.0 & 0.2 & 0.0 & 0.2 & 0.6 & 0.1 & 0.1 & 0.1 & 0.2 \\
\hline Total & 8.7 & 9.0 & 7.6 & 6.4 & 7.7 & 7.2 & 8.5 & 7.5 & 7.8 \\
\hline Micrinite & 0.2 & 0.0 & 0.0 & 0.0 & 0.0 & 0.0 & 0.0 & 0.0 & 0.0 \\
\hline Macrinite & 0.4 & 0.0 & 0.0 & 0.0 & 0.0 & 0.0 & 0.0 & 0.0 & 0.0 \\
\hline Semifusinite & 1.8 & 0.4 & 2.9 & 1.2 & 3.0 & 1.3 & 2.0 & 1.3 & 1.7 \\
\hline Fusinite & 3.6 & 0.2 & 0.8 & 1.9 & 3.3 & 0.6 & 3.4 & 2.2 & 2.0 \\
\hline Funginite & 0.2 & 0.2 & 0.6 & 0.2 & 0.1 & 0.2 & 0.5 & 0.6 & 0.3 \\
\hline Secretinite & 0.0 & 0.0 & 0.0 & 0.0 & 0.0 & 0.1 & 0.0 & 0.1 & 0.0 \\
\hline Inertodetrinite & 0.2 & 0.0 & 0.0 & 1.2 & 1.5 & 0.4 & 0.7 & 0.6 & 0.6 \\
\hline Total & 6.3 & 0.8 & 4.3 & 4.5 & 7.8 & 2.6 & 6.6 & 4.7 & 4.7 \\
\hline Sulphide & 1.4 & 1.8 & 1.6 & 1.6 & 0.9 & 1.9 & 1.5 & 2.3 & 1.6 \\
\hline Carbonate & 0.8 & 0.6 & 0.8 & 1.0 & 0.4 & 0.7 & 0.7 & 0.7 & 0.7 \\
\hline Argillaceous & 10.5 & 8.8 & 9.6 & 10.7 & 7.2 & 10.0 & 7.3 & 10.0 & 9.2 \\
\hline Total & 12.6 & 11.1 & 11.9 & 13.2 & 8.5 & 12.5 & 9.5 & 13.0 & 11.5 \\
\hline
\end{tabular}

Seams V-VIII have 3 composite samples each; Seam IV has 4 composite samples; and Seams I-III haves 5 composite samples each

with argillaceous minerals. Rounded to oval corpohuminite, usually occurs in clusters associated with ulminite. Among liptinites (8.8 vol\%, mean of all the seams on mmf basis), resinite $(5-40 \mu \mathrm{m})(5 \%)$ sporinite $(1.1 \%)$, cutinite $(0.5 \%)$ are common. Few sections show megaspores and megacuticles. Few patches of suberinite are seen showing clearly developed cortex cells. Bituminite grains in few patches were also identified under UV light. Among inertinites ( $5.3 \mathrm{vol} \%$, mean of all the seams on $\mathrm{mmf}$ basis), fusinite $(2.2 \%)$ with bogen structure was observed, especially in Seam-IV and VIII; funginite is common and occurs as telutospore as well as multichambered bodies of oval to rounded shape having up to $70 \mu \mathrm{m}$ in size. Seam-I and Seam-VI from Giral mine have shown good fungal bodies. Mineral matter (11.6 vol\%, mean of all the seams) occurs in moderate concentration in all the seams at Giral mine (Table 2a, b). Characteristic macerals are shown in photomicrographs (Fig. 3). The relative abundance of maceral groups and mineral matter of various seams in the Giral lignite mine is shown in Fig. 4.

Analysis of microlithotype has been performed simultaneously with maceral counting and is based on the classification scheme of Singh et al. (2010a, b). Humite (76.5 vol\%, mean of all the seams) is the dominant microlithotype in all the lignite samples of Barmer basin. Other monomacerites (liptite and inertite) and bimacerites (clarite- $\mathrm{H}$, clarite-E, huminertite- $\mathrm{H}$, huminertite-I, durite-I and durite-E) occur in small concentrations. The details of the microlithotypes are furnished in Table $2 b$. 
Table 2b Maceral composition (vol\%) of mineral matter free basis of Barmer Basin lignite, Rajasthan

\begin{tabular}{|c|c|c|c|c|c|c|c|c|c|}
\hline Seam no. & VIII & VII & VI & $\mathrm{V}$ & IV & III & II & I & Mean of all seams \\
\hline Textinite-A & 0.0 & 0.2 & 0.0 & 0.0 & 0.1 & 0.0 & 0.0 & 0.1 & 0.1 \\
\hline Textinite-B & 0.0 & 0.4 & 0.2 & 0.0 & 0.0 & 0.2 & 0.1 & 0.1 & 0.1 \\
\hline Ulminite-A & 27.3 & 12.3 & 31.8 & 22.8 & 25.1 & 21.3 & 25.6 & 29.3 & 24.4 \\
\hline Ulminite-B & 20.5 & 11.9 & 15.8 & 19.9 & 27.0 & 24.6 & 21.4 & 25.9 & 20.9 \\
\hline Attrinite & 12.6 & 10.5 & 2.7 & 12.3 & 7.2 & 4.3 & 6.2 & 4.7 & 7.6 \\
\hline Densinite & 21.2 & 53.2 & 36.0 & 31.8 & 22.7 & 38.1 & 29.5 & 24.9 & 32.2 \\
\hline Phlobaphinite & 1.1 & 0.4 & 0.0 & 0.7 & 1.0 & 0.4 & 0.5 & 1.1 & 0.6 \\
\hline Total & 82.8 & 89.0 & 86.4 & 87.5 & 83.0 & 88.9 & 83.3 & 86.0 & 85.9 \\
\hline Sporinite & 1.6 & 0.7 & 2.2 & 0.2 & 0.8 & 0.8 & 1.7 & 1.1 & 1.1 \\
\hline Cutinite & 0.9 & 0.9 & 0.2 & 0.2 & 0.3 & 0.2 & 0.8 & 0.7 & 0.5 \\
\hline Resinite & 5.6 & 6.9 & 4.2 & 4.7 & 4.8 & 5.0 & 4.7 & 4.5 & 5.0 \\
\hline Suberinite & 0.0 & 0.0 & 0.4 & 0.0 & 0.0 & 0.0 & 0.0 & 0.0 & 0.1 \\
\hline Liptodetrinite & 1.4 & 1.3 & 1.1 & 1.3 & 1.5 & 2.0 & 1.7 & 1.7 & 1.5 \\
\hline Bituminite & 0.0 & 0.0 & 0.0 & 0.0 & 0.0 & 0.0 & 0.0 & 0.0 & 0.0 \\
\hline Fluorinite & 0.5 & 0.0 & 0.4 & 0.7 & 0.4 & 0.0 & 0.4 & 0.5 & 0.4 \\
\hline Alginite & 0.0 & 0.2 & 0.0 & 0.2 & 0.6 & 0.1 & 0.1 & 0.2 & 0.2 \\
\hline Total & 9.9 & 10.1 & 8.7 & 7.4 & 8.4 & 8.2 & 9.4 & 8.6 & 8.8 \\
\hline Micrinite & 0.2 & 0.0 & 0.0 & 0.0 & 0.0 & 0.0 & 0.0 & 0.0 & 0.0 \\
\hline Macrinite & 0.5 & 0.0 & 0.0 & 0.0 & 0.0 & 0.0 & 0.0 & 0.0 & 0.1 \\
\hline Semifusinite & 2.0 & 0.4 & 3.3 & 1.3 & 3.2 & 1.4 & 2.2 & 1.4 & 1.9 \\
\hline Fusinite & 4.1 & 0.2 & 0.9 & 2.2 & 3.6 & 0.7 & 3.8 & 2.5 & 2.2 \\
\hline Funginite & 0.2 & 0.2 & 0.7 & 0.2 & 0.1 & 0.2 & 0.5 & 0.7 & 0.4 \\
\hline Secretinite & 0.0 & 0.0 & 0.0 & 0.0 & 0.0 & 0.1 & 0.0 & 0.1 & 0.0 \\
\hline Inertodetrinite & 0.2 & 0.0 & 0.0 & 1.3 & 1.6 & 0.5 & 0.8 & 0.7 & 0.6 \\
\hline Total & 7.2 & 0.9 & 4.9 & 5.1 & 8.5 & 2.9 & 7.3 & 5.4 & 5.3 \\
\hline
\end{tabular}

Seams V-VIII have 3 composite samples each; Seam IV has 4 composite samples; and Seams I-III haves 5 composite samples each

\subsection{Chemical attributes}

Proximate analysis indicates that Barmer lignites have a moderate ash content (mean $17.0 \mathrm{wt} \%$ of all I-VIII seams) while seam-IV has a low ash yield of $10.0 \%$. The mean volatile matter (daf) content for all the seams is $56.3 \%$. The details of the proximate constituents are given in Table 3. Ultimate analysis indicates that these lignite seams contain $70.7 \%$ carbon, $4.8 \%$ hydrogen, $1.9 \%$ nitrogen, $2.1 \%$ sulphur, and $20.5 \%$ oxygen (mean values of all the seams on daf basis). The average $\mathrm{H} / \mathrm{C}$ and $\mathrm{O} / \mathrm{C}$ ratios are 0.8 and 0.2 respectively. The details of chemical analyses are furnished in Table 3.

\subsection{Vitrinite reflectance and thermal maturity}

Barmer lignites have attained a thermal maturity up to 0.23-0.34 percent vitrinite reflectance ( $\mathrm{VRr}$ ) which may assign them 'low rank C' coals as per ISO-11760 (2005). The $\mathrm{T}_{\max }$ values in these lignites vary from 397 to $413{ }^{\circ} \mathrm{C}$ which maintains a strong positive correlation with $\mathrm{VRr}$ $(r=0.68)$ complementing each other. The immaturity of these lignites is also reflected in the $\mathrm{H} / \mathrm{C}-\mathrm{O} / \mathrm{C}$ plot (Fig. 5). Further, $\mathrm{C}_{\mathrm{daf}}$ maintains strong sympathetic correlations with vitrinite reflectance $(r=0.60)$ and with $\mathrm{T}_{\max }$ $(r=0.63)$ in these lignites. $\mathrm{VRr}$ maintains negative correlation with $\mathrm{O} / \mathrm{C}(r=-0.61)$ and with $\mathrm{H} / \mathrm{C}(r=-0.03)$ atomic ratios. This shows that coalification of these lignites is characterized by gain of carbon and loss of hydrogen and oxygen. This is also substantiated by a strong negative correlation $(r=-0.95)$ between oxygen index (OI) and hydrogen index (HI) (Table 4).

\subsection{Depositional environment}

Barmer lignites are strongly gelified because of anaerobic processes. True signatures of environment of the paleomire are imprinted on macerals as they directly relate to plants and environment. Presence or absence of certain macerals is related to the paleo depositional environment (Teichmüller 1989). Peat forming plant communities, nutrient supply, bacterial activity, types of deposition, temperature, 
$\mathrm{pH}$ and redox potential are the main controlling factors that characterize a coal (Teichmüller et al. 1998a, b; and Lin and Tian 2011). Inundation in the basin enhances the clastic mineral matter supply in the basin which is reflected in the coal by high ash yield. Reconstruction of the environment of paleomire of Barmer lignite basin has been attempted using petrography-based models. Cohen and Spackman (1972), Styan and Bustin (1983), Cohen et al.
(1987), Calder et al. (1991), Grady et al. (1993), Hawke et al. (1996), Singh and Singh (1996), Shearer and Clarkson (1998), Sun et al. (1998), Jasper et al. (2010), Singh et al. (2010a, b), (2012a, b, c), Deng and Sun (2011), and have successfully reconstructed the paleoecological environment using petrological studies.

Diesel (1986) used gelification index (GI) and tissue preservation index (TPI) for characterizing the paleomire
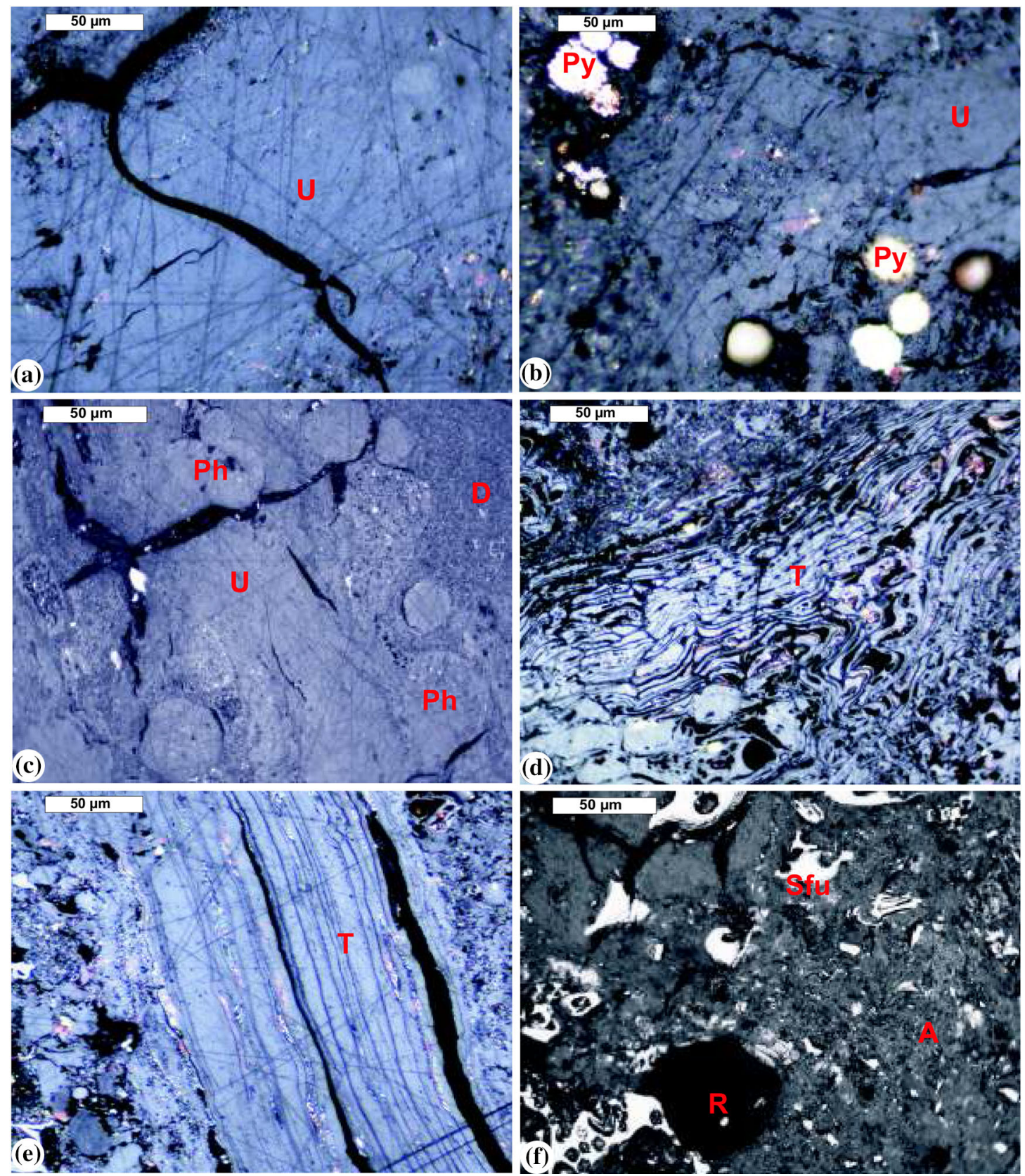

Fig. 3 Characteristic photomicrographs in the lignites of Barmer basin: a ulminite (U) with cracks; b ulminite and pyrite (Py); c ulminite, phlobaphinite $(\mathrm{Ph})$ and densinite (D); $\mathbf{d}$ textinite (T) showing compressed cell cavities; e textinite showing lamellar strcture; $\mathbf{f}$ attrinite (A), resinite (R) and inertodetrinite (Id); $\mathbf{g}$ fusinite $(\mathrm{Fu}) ; \mathbf{h}$ fusinite showing elongated cells; $\mathbf{i}$ attrinite, funginite $(\mathrm{F})$ and macrinite $(\mathrm{Ma}) ; \mathbf{j}$ suberinite $(\mathrm{Sb})$; $\mathbf{k}$ cutinite $(\mathrm{Cu})$ and sporinite $(\mathrm{Sp}) ; \mathbf{I}$ megasporinite $(\mathrm{Sp})$ 

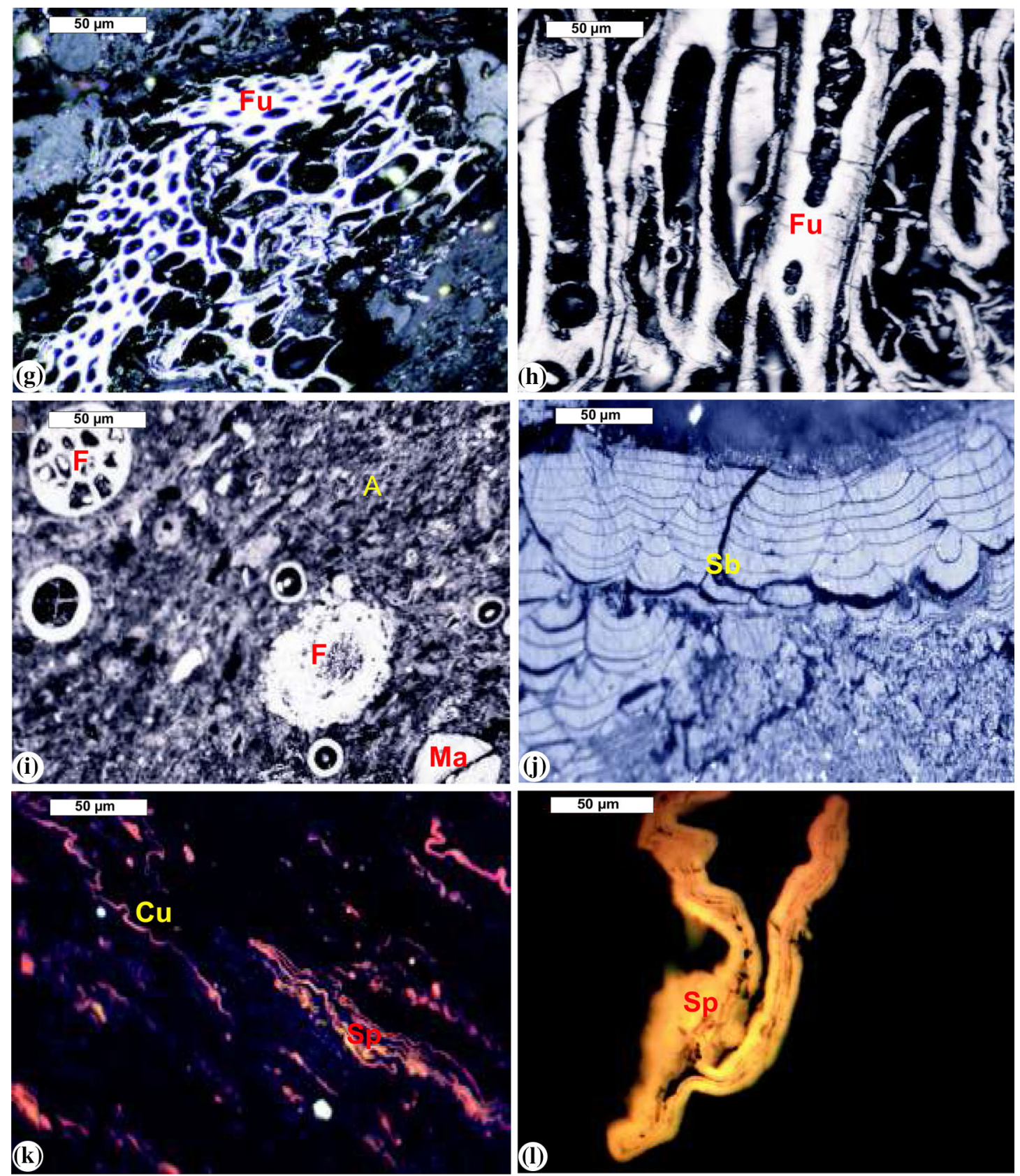

Fig. 3 continued

of Permian coals of Australia. Less-humified structured and strongly-humified unstructured tissue-derived macerals reveal vegetation type and degree of humification (Diesel 1992). While a high subsidence rate of a basin is reflected by high TPI and wood-derived tissues, a low TPI is indicative of subsidence with enhanced humification due to dominating herbaceous vegetation in the mire. On the other hand, the degree of gelification of huminite macerals is indicated by GI which differentiates gelified macerals from the ungelified ones. A continuous presence of water is prerequisite for gelification and fluctuation in water table affects GI because during the periods of drier spells inertinites would form. Many researchers have used palynological and paleobotanical data which provides higher precision in the determination of paleoenvironment (Calder 1993; Collinson and Scott 1987). Moreover, several researchers made serious remarks for using these indices for low-rank coals (Lambersen et al. 1991; Crosdale 1993; Dehmer 1995; Wüst et al. 2001; Scott 2002a, b; Moore and Shearer 2003; Amijaya and Littke 2005). As a result of 


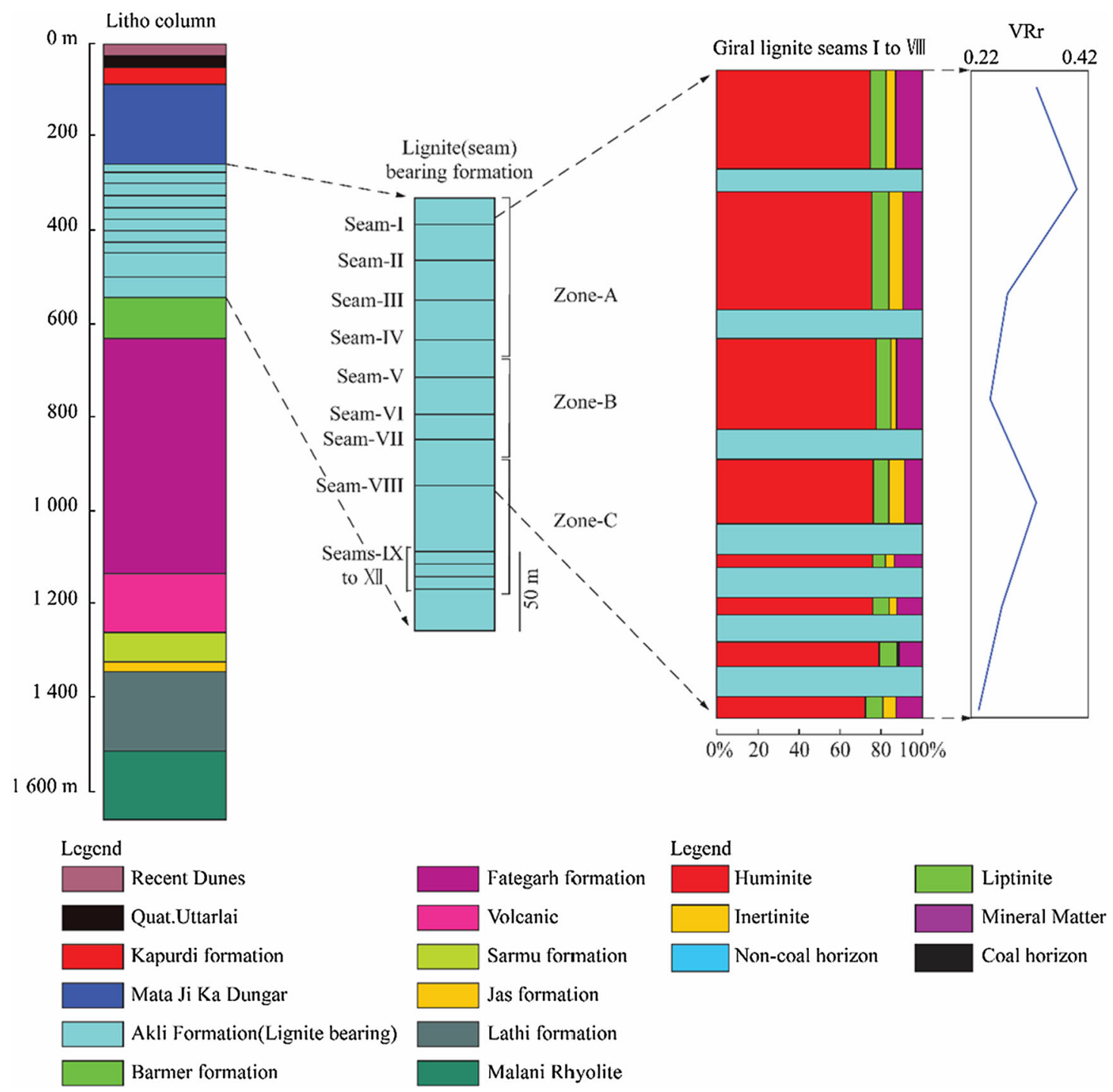

Fig. 4 Vertical variation of petrographic constituents in the lignites of Barmer at Giral and Kapurdi

this, few researchers used a combination of petrographic, organic geochemical, and/or isotope data to understand the environment of paleomire (Bechtel et al. 2002, 2003; Singh et al. 2013) while few researchers modified these indices for low-rank coals (Kalkreuth et al. 1991; Petersen 1993; Flores 2002).

It is often argued about the inclusion of inertinite macerals in the formula because inertinites may be washed or blown in the mire system or it may result due to crownfires and not necessarily a result of dry condition (Calder et al. 1991; Scott 2002a, b). Further, Moore and Shearer (2003) believe that coal type is related to degree of degradation of peat and not a function of climate, depositional environment, or tectonic setting. Mineral matter also provides important clue for environmental interpretation (Amijaya and Littke 2005; Singh and Singh 1996).
For the present study the indices have been calculated as per Petersen (1993) to reconstruct the environment of paleomire.

Barmer lignites are characterized by a very high GI and moderate TPI which are indicative of a continuous wet condition prevailing in the basin and a moderate subsidence rate during the decay of organic matter. Hoekel (1989) believes that intensive gelification of plant tissues results from acid ground water which is because of marine influence. This could also be the case with Barmer lignites. The detrital huminite relates to decay of plant material under telmatic to limno-telmatic environment. GI values exceeding 10 in all the seams indicate a topogenous mire in the Giral lignite field of Barmer basin which was permanently flooded. The GI and TPI values indicate that the these lignites originated mostly under wet forest swamp to 
Table 3 Microlithotype composition (vol\%) of Barmer Basin lignite, Rajasthan (as per classification scheme of Singh et al. 2010a, b)

\begin{tabular}{llrrrrrrrrrr}
\hline Item & Seam no. & VIII & \multicolumn{1}{c}{ VII } & \multicolumn{1}{c}{ VI } & V & IV & III & II & I & Mean of all seams \\
\hline Microlithotype & Humite & 71.9 & 81.2 & 78.2 & 78.3 & 77.6 & 77.1 & 74.2 & 73.7 & 76.5 \\
& Liptite & 3.8 & 3.4 & 2.4 & 2.8 & 2.9 & 2.8 & 3.8 & 2.9 & 3.1 \\
& Inertite & 3.0 & 0.4 & 1.8 & 1.6 & 3.2 & 1.1 & 2.8 & 2.1 & 2.0 \\
& Clarite-H & 2.4 & 2.0 & 1.8 & 1.4 & 2.1 & 1.9 & 2.1 & 1.8 & 1.9 & 1.9 \\
& Clarite-E & 1.8 & 1.2 & 1.4 & 0.4 & 1.5 & 1.5 & 1.5 & 1.2 & 1.3 \\
& Huminertite-H & 2.0 & 0.6 & 1.6 & 1.8 & 2.7 & 1.3 & 2.2 & 1.8 & 1.8 \\
& Huminertite-I & 1.4 & 0.0 & 1.0 & 0.8 & 1.6 & 0.6 & 1.2 & 0.8 & 0.9 \\
& Durite-I & 1.2 & 0.4 & 0.8 & 0.6 & 0.8 & 0.7 & 0.7 & 0.4 & 0.7 \\
& Durite-E & 0.2 & 0.0 & 0.2 & 0.4 & 0.3 & 0.4 & 0.2 & 0.3 & 0.3 \\
& Total & 87.6 & 89.2 & 89.1 & 88.1 & 92.6 & 87.3 & 88.8 & 85.0 & 88.5 \\
& Carbargilite & 9.5 & 8.1 & 8.3 & 9.8 & 5.2 & 9.9 & 8.8 & 11.7 & 8.9 \\
& Carbopyrite & 2.2 & 1.8 & 2.0 & 1.6 & 1.3 & 2.0 & 1.9 & 2.4 & 1.9 \\
& Carbankerite & 0.6 & 0.6 & 0.4 & 0.6 & 0.8 & 0.5 & 0.4 & 0.7 & 0.6 \\
& Carbopolyminerite & 0.2 & 0.4 & 0.2 & 0.0 & 0.2 & 0.3 & 0.2 & 0.3 & 0.2 \\
& Total & 12.5 & 10.9 & 10.9 & 12.0 & 7.4 & 12.7 & 11.2 & 15.0 & 11.6 \\
\end{tabular}

Seams V-VIII have 3 composite samples each; Seam IV has 4 composite samples; and Seams I-III haves 5 composite samples each

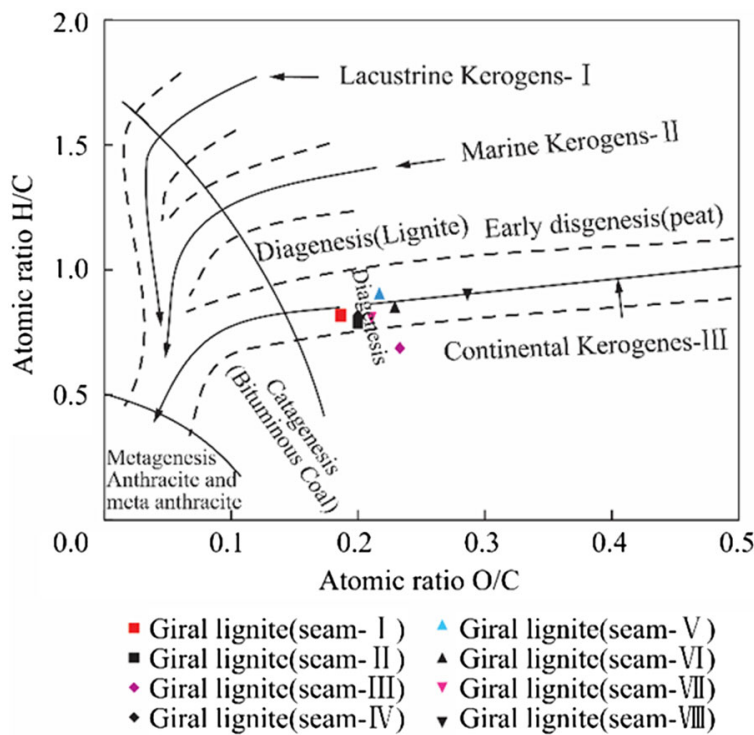

Fig. 5 Position of Barmer lignites in Van Krevelen diagram of H/C versus O/C atomic ratios (modified from Van Krevelen 1961)

clastic marsh having telmatic to limno-telmatic condition (Fig. 6) with a moderate rate of subsidence and a very slow fall in ground water table. The correlation between TPI and argillaceous mineral matter and also between GI and argillaceous mineral matter is insignificant in the investigated area. The Barmer lignites are moderately high in sulphur content which could be due to their association with brackish water. Several authors have observed such associations. Elevated sulphur content reveals that either the peat is connected to brackish water (Bustin and Lowe
1987; Casagrande 1987) or the seam is overlain by marine sediments (Cohen et al. 1984). This can be further substantiated by the studies on modern peats being formed under marine influence which have revealed the enrichment of sulfur due to sulphate reducing bacteria. This also results into precipitation of pyrite in peat (Querol et al. 1989; Phillips et al. 1994). A strong positive correlation $(r=0.850)$ between sulphur and ash further indicates that $\mathrm{pH}$ of the paleomire was raised due to infilling water which kept diluting humic acids. The $\mathrm{pH}$ would have been further raised by the carbonate-rich surface waters. This could have attributed for the higher sulphur content. The positive correlation between ash content and sulphur content further suggests that clastic sedimentation enhances the tree density and tissue preservation in the Barmer basin. Similar observation was also noticed in Nagaland coals of northeastern India (Singh et al. 2012a, b, c).

The influence of ground water on the environment of paleomire has been emphasised by Calder et al. (1991) and he used ground water influence index (GWI) and vegetation index (VI). Mires form in successive variations between rheotrophic and ombrotrophic hydrological conditions. Rheotrophic hydrological condition is characterized by relatively more high GWI values $(>1)$ while ombrotrophic to mesotrophic paleoenvironments are characterized by low GWI values $(<1)$. GWI values $>5$ are indicative of drowning of peat. The GWI and VI values of lignites of Barmer basin is suggestive of mesotrophic to rheotrophic hydrological conditions (Fig. 7) having the dominance of herbaceous to marginal aquatic vegetation. There were spells of periodic drowning of peat, especially 
Table 4 Summary of proximate and ultimate constituents (wt \%) of various lignite seams of Barmer Basin, Rajasthan

\begin{tabular}{|c|c|c|c|c|c|c|c|c|c|c|}
\hline \multirow[t]{2}{*}{ Seam } & \multirow[t]{2}{*}{ Ash $(\%)$} & \multicolumn{7}{|c|}{ Dry ash free basis } & \multirow[t]{2}{*}{ TOC $(\%)$} & \multirow[t]{2}{*}{ Lithotype } \\
\hline & & VM & $\mathrm{FC}$ & $\mathrm{C}$ & $\mathrm{H}$ & $\mathrm{N}$ & $\mathrm{S}$ & $\mathrm{O}$ & & \\
\hline Seam-I & 23.0 & 59.4 & 40.6 & 73.1 & 5.0 & 2.1 & 2.3 & 17.5 & 32.5 & Stratified black \\
\hline Seam-II & 15.6 & 54.6 & 45.4 & 72.1 & 4.7 & 1.9 & 2.0 & 19.3 & 41.6 & Stratified black \\
\hline Seam-III & 19.4 & 54.6 & 45.4 & 70.7 & 4.1 & 2.0 & 2.1 & 21.1 & 53.8 & Stratified black \\
\hline Seam-IV & 9.2 & 54.0 & 46.0 & 72.4 & 4.9 & 1.7 & 1.9 & 19.0 & 51.0 & Stratified black \\
\hline Seam-V & 18.3 & 59.2 & 40.8 & 69.9 & 5.2 & 2.0 & 2.0 & 20.9 & 35.4 & Stratified black \\
\hline Seam-VI & 14.6 & 61.7 & 38.3 & 69.8 & 4.9 & 1.9 & 2.0 & 21.4 & NA & Stratified black \\
\hline Seam-VII & 13.0 & 53.7 & 46.3 & 71.6 & 4.8 & 1.9 & 2.0 & 19.6 & 14.8 & Stratified black \\
\hline Seam-VIII & 16.9 & 56.8 & 43.2 & 66.0 & 4.9 & 1.8 & 2.0 & 25.3 & 42.5 & Stratified black \\
\hline
\end{tabular}

Seams V-VIII have 3 composite samples each; Seam IV has 4 composite samples; and Seams I-III haves 5 composite samples each

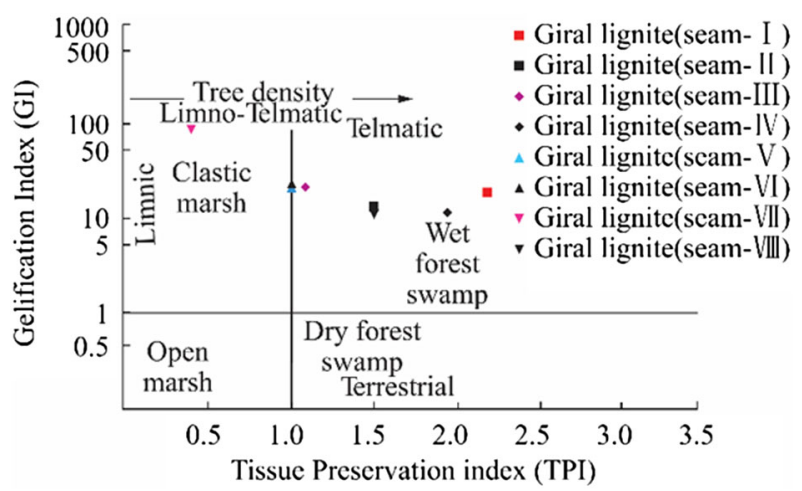

Fig. 6 Coal facies determined from Gelification Index (GI) and the Tissue Preservation Index (TPI) in relation to depositional setting and type of mire for the lignites of Barmer basin (modified from Diessel 1986)

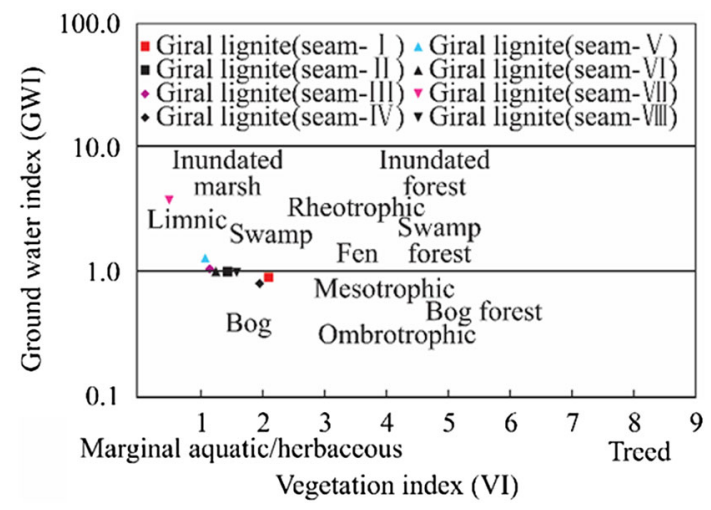

Fig. 7 Plots of ground water influence index (GWI) versus vegetation index (VI) for the lignites of Barmer basin (after Calder et al. 1991)

during the formation of Seam-VII. Variation of GI, TPI, GWI, and VI values from Seam-I to Seam VIII in Barmer basin is shown in Fig. 8. A ternary facies model based on maceral composition, modified from Mukhopadhyay
(1986), has been used to understand the environment of deposition of Barmer lignites. The plots are not exactly within the field of either forest swamp or reed marsh. Nevertheless, the plots cluster more towards forest swamp with tissue preservation (Fig. 9). For Rajpardi Eocene lignite deposit of adjacent Cambay basin, Singh et al. (2012a, b , c) proposed a ternary model based on macerals and clastic minerals. The plots of Barmer lignites on this model (Fig. 10) suggest that these lignites originated in wet moors with moderate to high flooding. The tissue preservation was moderate, but few sections have shown low preservation of tissue which is also reflected in the TPI values. Calcium-rich coals are understood to suffer severe structural decomposition through bacterial activity leading to the formation of humic gels (Teichmüller et al. 1998a). Subsequently, the bacterial degradation of the plant remains will lead to bacterial reduction of sulphates and ulminites would be formed in high concentration. Further, Teichmüller et al. (1998a) believe that presence of substantial amount of detrohuminite favours its formation under aerobic condition. Kuder et al. (1998) have discussed the tectonic implications of peat beds. The concentration of moderately high concentration of calcium (1.2\%$4.7 \mathrm{wt} \%$ ) in the Barmer lignites along with the presence of framboidal pyrite indicate enhanced sulphate-reducing bacterial activity present in the carbonate- and sulphaterich waters of the basin at the time of peat formation which is in agreement with the views of Kuder et al. (1998) and Teichmüller et al. (1998a). Marine influence in the Barmer basin is indicated by pyrite framboids which formed through the bacterial activity.

On the basis of sedimentological studies, Sisodia and Singh (2000) believe that the Akli Formation was formed over a flood plain which suffered marine incursion. Habib et al. (1994) suggested its formation close to the paleoshoreline on the basis of terrestrial organic matter and dinoflagellate cysts recovered from the black shales and 
gray clay. Tripathi et al. (2009) speculated that the Akli Formation was formed in a paleoshoreline having extensive swamps which were fringed by abundant mangrove Nypa palms. They have reported the abundance of tropical flora such as pteridophytic spores. Further, the presence of Microthyriaceous fungal fruits indicates warm and humid condition and high precipitation.

The depositional environment of coal also influences its sulphur content (Berner and Raisewell 1983; Littke et al. 1991; Lallier-Vergès et al. 1997; Jasper et al. 2010). Since sea water contains high sulphur as compared to fresh water, it is generally observed that the coal seams overlain by marine horizons are enriched in sulphur content. Berner and Rsaisewell (1983) suggested that S/TOC ratio of fresh water sediments is less than that in marine sediments. The $S$ versus TOC plot (after Jasper et al. 2010) for the Barmer lignites is shown in Fig. 11. In this plot Jasper et al. (2010) grouped the coals in three domains. Group A is for coals with high TOC and low sulphur content $(<2 \%)$, such as evolved under ombrogenous mires having raised bogs fed by rainwater. Group $\mathrm{C}$ is characterized by coals having high-sulphur content and formed as topogenous mires. Group B shows an intermediate condition. Most of the lignites samples of the Barmer basin fall within Group $\mathrm{C}$ and represent a topogenous condition of formation. However, three samples belonging to one each from seams-I, V, and VII of the Giral mine having less than $30 \%$ TOC fall out of Group C. This is also in agreement with the result obtained through the ground water index of Calder et al.

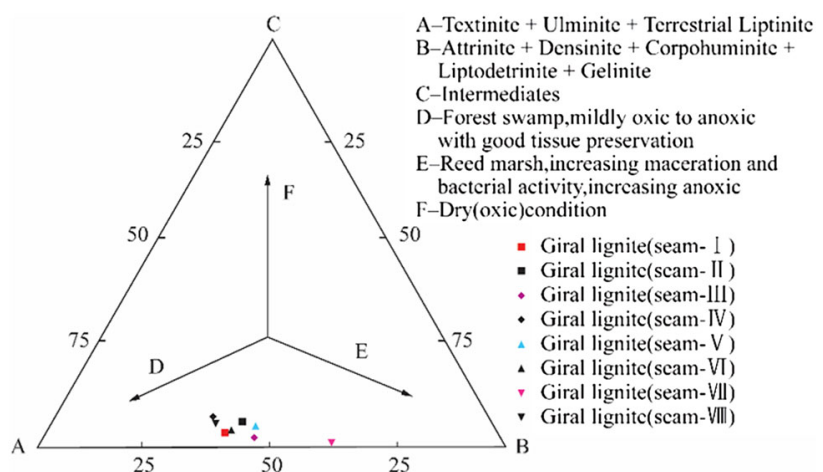

Fig. 9 Ternary diagram illustrating facies- critical maceral associations in lignites of Barmer Basin and suggested peat forming environments (modified from Mukhopadhyay 1986)

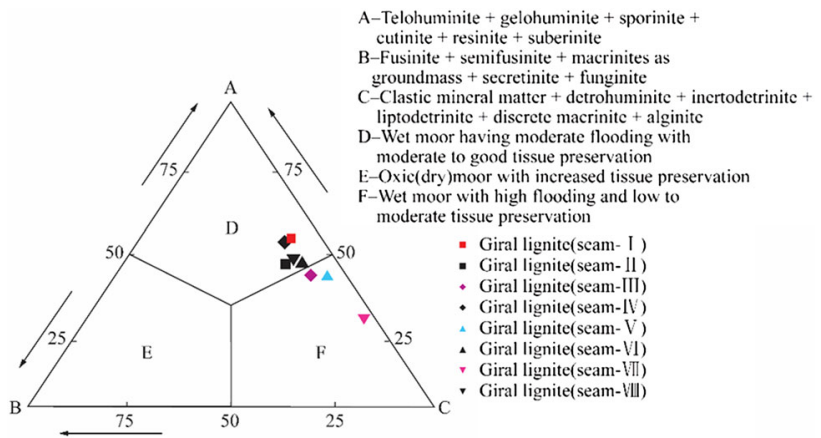

Fig. 10 Peat forming environment of lignites of Barmer basin based on microlithotype (after Singh et al. 2012a, b, c)
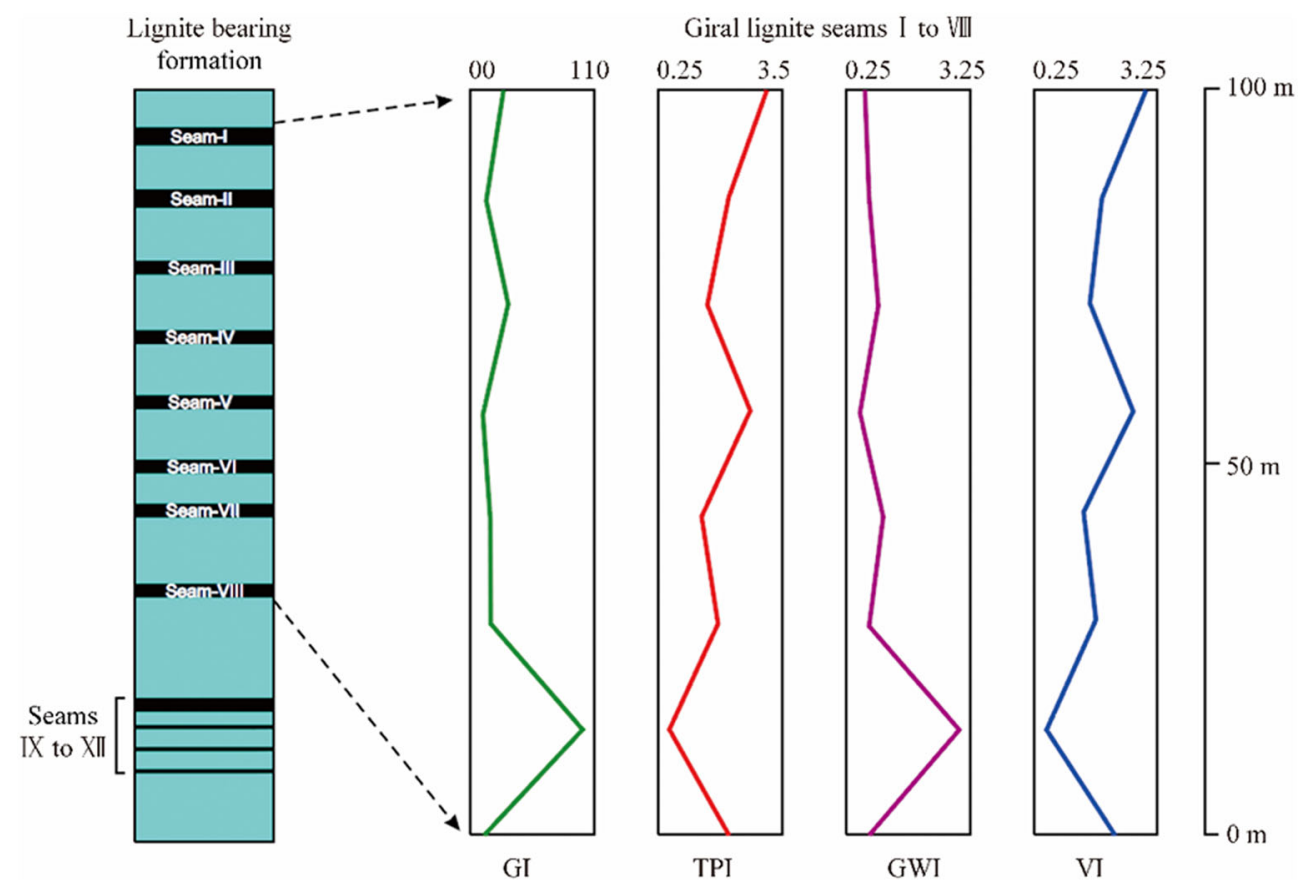

Fig. 8 Variation of GI, TPI, GWI and VI with depth in the lignites seams of Barmer Basin 


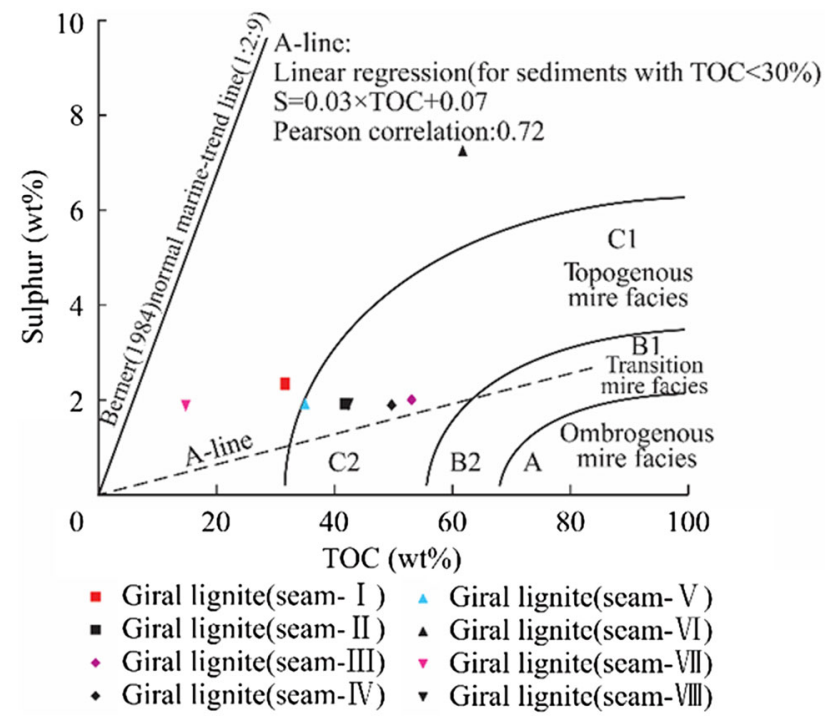

Fig. 11 Plot of sulphur (wt $\%$ ) versus TOC (wt $\%$ ) for the lignites of Barmer Basin

(1991). Haq et al. (1987) discussed the Early Paleogene eustatic sea level rise of 70-140 m higher than the present day sea level. This is supported by the records preserved in the late Paleocene-early Eocene sedimentary sequences formed due to global transgressions during 58.5-52.8 Ma (Sluijs et al. 2008). Further, Haq et al. (1987) and Hardenbol et al. (1998) have suggested that during 55-52 Ma the eustatic sea-level curve was high in spite of small scale fluctuations. The ternary model of Singh et al. (2010a, b) based on microlithotype composition of lignites, which was initially proposed for understanding the paleodepositional environment of Vastan Eocene lignite deposit of adjacent Cambay basin, also supports this view. The data of Barmer lignites on this model indicates that they formed in a wet moor with moderate flooding where increasing bacterial activity prevailed. Due to very high concentration of huminite the samples are clustered towards 'A' corner (Fig. 12).

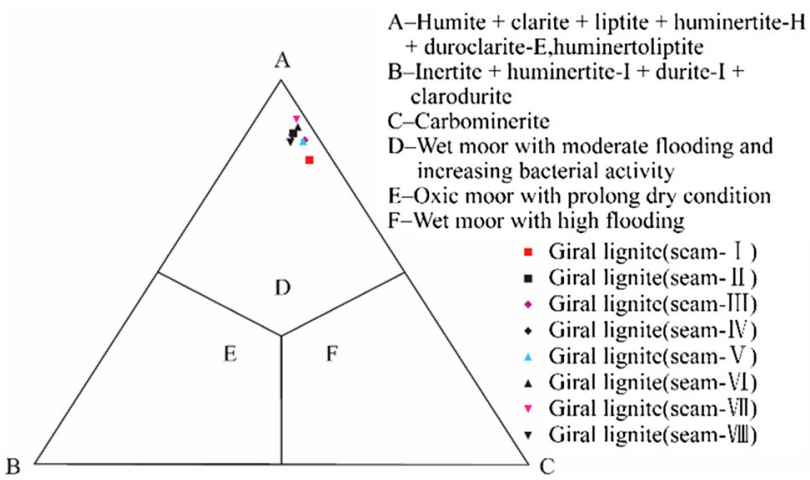

Fig. 12 Peat forming environment of lignites of Barmer Basin based on microlithotype (after Singh et al. 2010a, b)

\section{Conclusions}

In the present study the lignites of the Barmer basin (Rajasthan) have been subjected to petrological and chemical analyses to understand the evolution of their peat forming paleomires. The basin is the northward extension of the Cambay rift basin which is considered as a composite, second-order graben. The lignites occur in the Akli Formation. Its lower member is comprised of sandstones, lignites, and shales while the upper member contains bentonite clays. These lignite seams laterally and vertically grade into carbonaceous clay and lignite clay. The lignite seams are thin and the individual seams vary in thickness from 0.3 to $7.20 \mathrm{~m}$. Based on the present investigation, the following conclusions may be drawn:

(1) Megascopically, the lignite seams consist dominantly of stratified black bands, most of which contain patches of megascopic resin and a few of the lignites also show specks of pyrite.

(2) The lignites of the Barmer basin are chiefly composed of the huminite group of macerals while the liptinite and inertinite group macerals occur in low concentrations. There is not much variation in the maceral composition from Seam-I to Seam-VIII. Huminite (85.9 vol\%, mean of all the seams on $\mathrm{mmf}$ basis) is comprised mainly of telohuminite and detrohuminite. Telohuminite is mainly contributed by ulminite-A $(24.4 \%)$ and ulminite-B $(20.9 \%)$. Detrohuminite consists of densinite $(32.2 \%)$ and attrinite $(7.6 \%)$. Gelohuminite is present in very small amounts. Among the liptinites (8.8 vol\%, mean of all the seams on $\mathrm{mmf}$ basis), resinite $(5-40 \mu \mathrm{m})(5 \%)$ sporinite $(1.1 \%)$, cutinite $(0.5 \%)$ are common. Few sections show megaspores and megacuticles. Few patches of suberinite are seen, showing clearly developed cortex cells. Among the inertinites (5.3 vol\%, mean of all the seams on $\mathrm{mmf}$ basis), fusinite $(2.2 \%)$ with bogen structure was observed especially in Seam-IV and VIII. Seam-I and Seam-VI from the Giral mine have shown good fungal bodies. Mineral matter (11.6 vol\%, mean of all the seams) occurs in moderate concentration in all the seams of the Giral mine.

(3) These lignites have a moderate ash content (mean $17.0 \mathrm{wt} \%$ of all I-VIII seams) while seam-IV has a low ash yield of $10.0 \%$. The mean volatile matter (daf) content for all the seams is $56.3 \%$. Vitrinite reflectance (VRr) of $0.23 \%-0.34 \%$ assigns them as 'low rank C' coals. The $T_{\max }$ values in these lignites vary from 397 to $413{ }^{\circ} \mathrm{C}$, which has a strong positive correlation with $\operatorname{VRr}(r=0.68)$. 
(4) The Barmer lignites are characterized by a very high GI and moderate TPI which are indicative of a continuous wet condition prevailing in the basin with a moderate subsidence rate. GI values exceeding 10 in all the seams indicate topogenous mire in Barmer basin which was permanently flooded. The GI and TPI values and the petrography-based facies models indicate that the Barmer lignites originated mostly under wet forest swamp to clastic marsh having telmatic to limno-telmatic condition with a moderate rate of subsidence and a very slow fall in ground water table. Considering the thin lignite seams in the basin, it appears that peat accumulation could not keep pace with basin subsidence for long time and the subsidence exceeded peat accumulation rate. The strong positive correlation $(r=0.850)$ between ash content and sulphur content suggests that clastic sedimentation enhances the tree density and tissue preservation in the Barmer basin.

(5) The GWI and VI values of lignites of Barmer basin are suggestive of mesotrophic to rheotrophic hydrological conditions having the dominance of herbaceous to marginal aquatic vegetation. There were spells of periodic drowning of peat, especially during the formation of Seam-VII. The moderately high concentration of calcium $(1.2 \%-4.7 \mathrm{wt} \%)$ in the Barmer lignites along with the presence of framboidal pyrite are suggestive of enhanced sulphatereducing bacterial activity in the carbonate and sulphate-rich waters of the basin at the time of peat formation.

Acknowledgments The authors thankfully acknowledge the Department of Geology, Banaras Hindu University for extending the laboratory and other facilities. We thankfully acknowledge the help received for Rock-Eval-6 pyrolysis from the R \& D, Oil India Ltd, Duliajan. The authors also thank CMPDI, Ranchi for carrying out ultimate analysis.

Open Access This article is distributed under the terms of the Creative Commons Attribution 4.0 International License (http://crea tivecommons.org/licenses/by/4.0/), which permits unrestricted use, distribution, and reproduction in any medium, provided you give appropriate credit to the original author(s) and the source, provide a link to the Creative Commons license, and indicate if changes were made.

\section{References}

Amijaya H, Littke R (2005) Microfacies and depositional environment of Tertiary Tanjung Enim low rank coal, South Sumatra basin, Indonesia. Int J Coal Geol 61:197-221

Barooah SK (1946) The occurrence of the Laki Series in Jodhpur State. Curr Sci 15(II):317
Bechtel A, Sachsenhofer RF, Kolcon I, Gratzer R, Otto A, Puttmann W (2002) Organic geochemistry of the Lower Miocene Oberdorf lignite (Styrian Basin, Austria); its relation to petrography, palynology and the peleoenvironment. Int J Coal Geol 51:31-57

Bechtel A, Gruber W, Sachsenhofer RF, Gratzer R, Lucke A, Puttmann W (2003) Depositional environment of the Late Miocene Hausruck lignite (Alpine Foreland Basin); insights from petrography, organic geochemistry and stable carbon isotopes. Int J Coal Geol 53:153-180

Berner RA (1984) Sedimentary pyrite formation: an update. Geochim Cosmochim Acta 48:605-615

Berner RA, Raiswell R (1983) Burial of organic carbon and pyrite sulfur in sediments over Phanerozoic time: a new theory. Geochim Cosmochim Acta 47:855-862

Bhandari A (1999) Phanerozoic stratigraphy of Western Rajasthan basin: a review. In: Kataria P (Ed), Proc. seminar on geology of Rajasthan. Status and perspective (A. B. Roy Felicitation Volume), geology Dept. MLSU, Udaipur, pp 126-174

Bhattacharya NB, Datta A (1985) A report on the lignite occurrences around Botiya-Bharka-Thumbli area, Barmer district, Rajasthan. F.S. 1983-1984, Geological Survey of India, 1-8 (Unpublished)

Bhola KL (1946) Fuller's earth in India. Trans Ind Ceramic Soc $5(3): 104-124$

BIS (2003) Methods of test for coal and coke (2nd revision of IS: 1350). Part I, Proximate analysis. Bureau of Indian Standard, $1-29$

Bose RN (1956) Gravity and magnetic survey for exploration of oil in Jaisalmer area, (Rajasthan); Rec Geol Surv India 91(I):181-192

Bustin RM, Lowe LE (1987) Sulphur low temperature ash and minor elements in humid-temperate peat of the Fraser River Delta, British Columbia. J Geol Soc 144:435-450

Calder JH (1993) The evolution of a ground-water influenced (Westphalian B) peat-forming ecosystem in a piedmont setting: the No. 3 seam, Springhill coalfield, Cumberland Basin, Nova Scotia. In: Cobb JC, Cecil CB (eds), Modern and ancient coalforming environments. The Geological Society of America, Special Paper, Boulder, 153-180

Calder JH, Gibbing MR, Mukhopadhay PK (1991) Peat formation in a Westphalian B piedmont setting, Cumberland Basin, Nova Scotia: Implication for the maceral-based interpretation of rheotrophic and raised paleomires. Bull de la Soc Geol de France 162:283-298

Casagrande DJ (1987) Sulphur in peat and coal. In: Scott AC (ed), Coal and coal-bearing strata: recent advances. Geological Society Special Publication 32, Blackwell, Oxford, p 87-105

Cohen AD, Spackman W (1972) Methods in peat petrology and their application to reconstruction of paleoenvironments. Geol Soc Am Bull 83:129-142

Cohen AD, Spackman W, Deben P (1984) Occurrence and distribution of sulfur in peat forming environment of southern Florida. Int J Coal Geol 4:73-96

Cohen AD, Spackman W, Raymond R Jr (1987) Interpreting the characteristics of coal seams from chemical, physical and petrographic studies of peat deposits. In: Scott AC (ed), Coal and coal-bearing strata: recent advances. Geological Society of London, Special Publication 32:107-126

Collinson ME, Scott AC (1987) Implications of vegetational change through the geological record on models of coal-forming environments. In: Scott AC (ed), Coal and coal-bearing strata: recent advances. The Geological Society of America, Special Paper, Boulder, p 67-85

Compton PM (2009) The geology of the Barmer Basin, Rajasthan, India, and the origins of its major oil reservoir, the Fatehgarh formation. Petrol Geosci 15:117-130 
Crosdale PJ (1993) Coal maceral ratios as indicators of environment of deposition: do they work for ombrogenous mires? An example from the miocene of New Zealand. Org Geochem 20:797-809

Das Gupta SK (1974) Stratigraphy of western Rajasthan shelf. In: Proceedings IV Indian colloqium, micropalaeontology and stratigraphy, Dehradun, India

Dehmer J (1995) Petrological and organic geochemical investigation of recent peats with known environments of deposition. Int $\mathbf{J}$ Coal Geol 28:111-138

Deng XL, Sun YZ (2011) Coal petrological characteristics and coal facies of No. 11 seam from the antaibao mine, Ningwu coalfield, China. Energy Explor Exploit 29:313-324

Deshmukh GP, Mishra SP (1971) Geological mapping in parts of Barmer and Jaisalmer districts, Rajasthan, Unpub. Prog. Rep. F. S. 69-70, GSI

Diessel CFK (1982). On the reactivity of inertinite macerals in coal during carbonization. Univ. of Newcastle, Department Geology, Research report number 1

Diessel CFK (1986) On the correlation between coal facies and depositional environments. In Proceeding 20th Symposium of Department Geology, University of New Castle, New South Wales, pp 19-22

Diessel CFK (1992) Coal bearing depositional systems. Springer, Berlin, p 721

Flores D (2002) Organic facies and depositional palaeoenvironment of lignites from Rio Maior Basin (Portugal). Int $\mathrm{J}$ Coal Geol 48:181-195

Grady WC, Eble CF, Neuzil SG (1993) Brown coal maceral distributions in a modern domed tropical Indonesian peat and a comparison with maceral distributions in Middle Pennsylvanianage Appalachian bituminous coal beds. The Geological Society of America, Special Paper 286:63-82

Habib D, Eshet Y, Van Pelt R (1994) Palynology of sedimentary cycle. In: Traverse A (ed) Sedimentation of organic particles. Cambridge University Press, Cambridge, pp 311-335

Haq BU, Hardenbol J, Vail PR (1987) Chronology of fluctuating sea levels since the Triassic. Science 235:1156-1167

Hardenbol J, Thierry J, Farley MB, Jacquin T, de Graciansky PC, Vail PR (1998) Mesozoic and Cenozoic sequence chronostratigraphic framework of European basins. In Graciansky PC et al. (eds), Mesozoic and cenozoic sequence stratigraphy of european basins: SEPM (Society for Sedimentary Geology) Special Publication 60: 3-13

Hawke MI, Martini IP, Stasiuk LD (1996) Petrographic characteristics of selected Ontario peats: possible modern analogues for coals, 13th Annual Meeting TSOP, Abstracts and Program. Southern Illinois University, Carbondale Illinois, 22-23

Hiltman W (1976) Pollenanalytische untersuchungen im rheinischen hauptbraunkohlenflioz Der Tagebaue Frechen und Fortuna unter besonderer Berhcksichtigung der macropetrographischian Ausbildung der Kohle. Dissertation, Rheinisch-Westfalische Technische Hochschule Aachen, Aachen

Hoekel A (1989) On the plate tectonic setting of the coal deposits of Indonesia and the Phillippines. Mitt des Österr Geol Ges 82:119-133

Hunt JW, Brakel AT, Smyth M (1986) Origin and distribution of the Bayswater seam and correlatives in the Permian Sydney and Gunnedah Basins, Australia. Aust Coal Geol 6:59-75

ICCP (2001) The new inertinite classification (ICCP system 1994). Fuel 80:459-471

ISO 11760 2005. Classification of coals. International standard, pp 1-9

Jasper K, Hartkopf-Froder C, Flajs G, Littke R (2010) Evolution of Pennsylvanian (Late Carboniferous) peat swamps of the Ruhr Basin, Germany: comparison of palynological, coal petrographical and organic geochemical data. Int J Coal Geol 83:346-365
Jodha BS (2003) A final report on regional exploration for lignite in Mahabar-Shivkar area, Barmer district, Rajasthan F.S. 1999-2000 to 2001-2002 and 2002-2003 (part), Geological Survey of India (Unpublished)

Joshi DW, Bhattacharya NB, Datta A, Chakrabarty U, Das M (1990) A final report on the exploration lignite in Barmer district, Rajasthan F.S 1982-1983 to 1987-1988 (Unpublished)

Kalkreuth WD, Marchioni DL, Calder JH, Lamberson MN, Naylor RD, Paul J (1991) The relationship between coal petrography and depositional environments from selected coal basins in Canada. In: Kalkreuth WD, Bustin RM, Cameron AR (eds), Recent advances in organic petrology and geochemistry. A symposium honouring Dr. P. Hacquebard. Int J Coal Geol 19:21-76

Kuder T, Kruge MA, Shearer JC, Miller SL (1998) Environmental and botanical controls on peatification-a comparative study of two New Zealand restiad bogs using Py-GC/MS, petrography and fungal analysis. Int J Coal Geol 37:3-27

La Touch THD (1902) Geology of Western Rajputana. Mem Geol Surv Ind, vol 35, Pt. I

Lallier-Verges E, Hayes JM, Boussafir M, Zaback DA, Tribovillard NP, Connan J, Bertrand P (1997) Productivity-induced sulphur enrichment of hydrocarbon-rich sediments from the Kimmeridge clay formation. Chem Geol 134:277-288

Lamberson MN, Bustin RM, Kalkreuth W (1991) Lithotype (maceral) composition and variation as correlated with paleo-wetland environment, Gates Formation, Northeastern British Columbia, Canada. Int J Coal Geol 18:87-124

Lin MY, Tian L (2011) Petrographic characteristics and depositional environment of the No. 9 Coal (Pennsylvanian) from the Anjialing Mine, Ningwu Coalfield, China. Energy Explor Exploit 29:197-204

Littke R, Baker DR, Leythaeuser D, Rullkotter J (1991) Keys to depositional history of the Posidonia Shale (Toracian) in the Hils syncline, northern Germany. In: Tyson RV, Pearson TH (eds), Modern and ancient continental shelf anoxia, Geol. Soc. Spec. Publ., 58:311-334

McCabe PJ (1991) Geology of coal: environment of deposition. In: Gluskoter HJ et al. (eds), The Geology of North America, Geological Society of America, 2, Economic Geology, USA

Moore TA, Shearer JC (2003) Peat/coal type and depositional environment-are they related? Int J Coal Geol 56:233-252

Mukhopadhyay PK (1986) Petrography of selected Wilcox and Jackson group lignites from tertiary of Texas. In: Finkelman RB, Casagrade DJ (eds), Geology of Gulf Coast Lignites. 1986, Annual Meeting. Geological Society of America, Coal Geology Division, Field Trip, pp. 126-145

Oldham RD (1886) Geology of Northern Jaisalmer. Rec Geol Sur Ind 19:157-159

Petersen HI (1993) Petrographic facies analysis of lower and middle Jurassic coal seams on the island of Bomholm, Denmark. Int $\mathbf{J}$ Coal Geol 22:189-216

Phillips S, Bustin RM, Lowe LE (1994) Earthquake induced flooding of a tropical coastal peat swamp: a modern analogue for high sulfur coals? Geology 22:929-932

Querol X, Chinenon S, Lopez-Soler A (1989) Iron sulphide precipitation sequence in Albian coals from the Maestrazgo basin, southeastern Iberian range, northeastern Spain. Int J Coal Geol 11:171-189

Roy AB, Jakhar SR (2002) Geology of Rajasthan (Northwest India) precambrian to recent. Scientific Publishers, Jodhpur, pp 1-421

Schneider W (1978) Zu einigen Gesetzmähigkeiten der faziellen Entwicklung im 2. Lausitz. Flöz. Z Angew Geol 24(3):125-130

Schneider W (1980) Mikropalaontologische Faziesanalyse in der braunkohle. Neue Bergbautech 10:670-675

Schopf JM (1960) Field description and sampling of coal beds-bull. US Geol Surv 1111B:25-70 
Scott AC (2002a) The pre-quaternary history of fire. Palaeogeogr Palaeoclim Palaeocol 164:281-329

Scott AC (2002b) Coal petrology and the origin of coal macerals: a way ahead? Int J Coal Geol 50:119-134

Sharma KK (2007) K-T magmatism and basin tectonism in western Rajasthan, India, results from extensional tectonics and not from reunion plume activity. Foulger GR, Jurdy DM (eds), Plates, plumes and planetary processes. Geological Society of America Special Paper 430: pp 775-784

Shearer JC, Clarkson BR (1998) Whangamarino wetland: effects of lowered river levels on peat and vegetation. Int $\mathrm{J}$ Coal Geol $8: 52-65$

Siddiquie HN (1963) The jodhpur-malani divide separating the Barmer and Jaisalmer basins. Geol Soc India 4:97-107

Siddiquie HN, Bahl DP (1965) Geology of the bentonite deposits of Barmer distt; Rajasthan. Geol Soc India Mem. 96:1-96

Singh MP, Singh PK (1996) Petrographic characterization and evolution of the Permian coal deposits of the Rajmahal basin, Bihar, India. Int J Coal Geol 29:93-118

Singh PK, Singh MP, Singh AK, Arora M (2010a) Petrographic characteristics of coal from the Lati Formation, Tarakan basin, East Kalimantan. Int J Coal Geol 81:109-116

Singh PK, Singh MP, Singh AK (2010b) Petro-chemical characterization and evolution of Vastan Lignite, Gujarat, India. Int J Coal Geol 82:1-16

Singh PK, Singh MP, Singh AK, Naik AS, Singh VK, Singh VK, Rajak PK (2012a) Petrological and geochemical investigations of Rajpardi lignite deposit, Gujarat, India. Energy Explor Exploit 30:131-152

Singh PK, Singh MP, Singh AK, Naik AS (2012b) Petrographic and geochemical characterization of coals from Tiru valley, Nagaland, NE India. Energy Explor Exploit 30:171-192

Singh PK, Singh MP, Prachiti PK, Kalpana MS, Manikyamba C, Lakshminarayana G, Singh A, Naik AS (2012c) Petrographic characteristics and carbon isotopic composition of Permian coal: implications on depositional environment of Sattupalli coalfield, Godavari Valley, India. Int J Coal Geol 90-91:34-42

Singh PK, Singh GP, Singh MP, Naik AS (2013) The petrology of coals from the rampur seam-IV and the Lajkura seam, Ib River Coalfield, Mahanadi Valley, Orissa, India. Energy Sour, Part A: Recov Util Environ Eff 35:1681-1690

Sisodia MS, Singh UK (2000) Depositional environment and hydrocarbon prospects of the Barmer Basin, Rajasthan, India. NAFTA, Zagreb (Croatia) 51(9):309-326

Sluijs A, Brinkhuis H, Crouch EM, John CM, Handley L, Munsterman D, Bohaty SM, Zachos JC, Reichart GJ, Schouten S, Pancost RD, Sinninghe Damste JS, Welters LD N, Lotter AF, Dickens GR 2008. Eustatic variations during the PaleoceneEocene greenhouse world. Paleoceanography 23, PA4216

Styan WB, Bustin RM (1983) Petrography of some Fraser Delta peat deposits: coal maceral and microlithotype precursors in temperate-climate peats. Int J Coal Geol 2:321-370
Sun YZ, Wang BS, Lin MY (1998) Maceral and geochemical characteristics of coal seam 1 and oil shale 1 in fault-controlled Huangxian Basin, China. Org Geochem 29:583-591

SÝKorova I, Pickel W, Christanis M, Wolf K, Taylor GH, Flores D (2005) Classification of huminite. ICCP System 1994. Int J Coal Geol 62:85-106

Taylor GH, Teichmüller M, Davis A, Diessel CFK, Littke R, Robert P (1998) Organic petrology. Elsevier, Gebrüder Borntraeger, Berlin, p 704

Teichmüller M (1950) Zum petrographischen Aufbau und Werdegang der Weichbraunkoble (mit Berücksichtigung genetischer Fragen der Steinkohlenpetrgraphie). Geol Jb 64:429-488

Teichmüller M (1962) Die genese der kohle. C.R. 4th Congr. Int. Strat. Geol. Carbonifere, Heerlen 1958, Maastricht, 3:699-722

Teichmüller M (1989) The genesis of coal from the viewpoint of coal petrology. In: Lyons PC, Alpern B (eds) Peat and coal: origin, facies and depositional models. Springer, Berlin, pp 1-87

Teichmüller M, Thomson PW (1958) Vergleichende mikroskopische und chemische Untersuchungen der wichtigsten Fazies-Typen im Hauptfloz der niederrheinischen Braunkohle. Fortschr Geol Rheinld U Westf 2:573-598

Teichmüller M, Littke R, Taylor GH (1998a) The origin of organic matter in sedimentary rocks. In: Taylor GH, Teichmüller M, Davis A, Diessel CFK, Littke R, Robert P (eds) Organic petrology. Gebrüder Borntraeger, Berlin, p 704

Teichmüller M, Taylor GH, Littke R (1998b) The nature of organic matter-macerals associated minerals. In: Taylor GH, Teichmuller M, Davis A, Diessel CFK, Littke R, Robert P (eds) Organic petrology. Gebrüder Borntraeger, Berlin, p 704

Thompson PW (1951) Die sukzession der Pflanzenvereine und moortypen im hauptflöz der rheinischen braunkohle mit einer ubersichr vegetationsentwickelung der rheinischen braunkohle in Liblar, Neurahh, Fortuna und Bruhl. Ber Geobot Forsch Inst Rubel, pp 81-87

Tripathi SKM, Kumar M, Srivastava D (2009) Palynology of lower palaeogene (Thanetian-Ypresian) coastal deposits from the Barmer Basin (Akli Formation, Western Rajasthan, India): palaeoenvironmental and palaeoclimatic implications. Geol Acta $7: 147-160$

Van Krevelen DW (1961) Coal: typology-chemistry-physics-constitution. Elsevier Science, Amsterdam, p 514

Von der Brelie G, Wolf M (1981) Zur petrographie und palynologie heller und dunkler schichten im rheinischen hauptbraunkohlenfloz. Fortschr Geol Rheinld U Westf 29:95-163

Wust RAJ, Hawke MI, Bustin RM (2001) Comparing maceral ratios from tropical peatlands with assumption from coal studies; do classic coal petrographic interpretation methods have to be discarded? Int J Coal Geol 48:115-132 